\title{
Poplar Afforestation Effects on Grassland Structure and Composition in the Flooding Pampas
}

\author{
M. del Pilar Clavijo, ${ }^{1}$ Marisa Nordenstahl, ${ }^{2}$ Pedro E. Gundel, ${ }^{1}$ \\ and Esteban G. Jobbágy \\ Authors are ${ }^{1}$ Graduate and ${ }^{2}$ Undergraduate Students in Facultad de Agronomia, Universidad de Buenos Aires, \\ Av San Martin 4453 (1417), Buenos Aires, Argentina; and ${ }^{3}$ Research Scientist, CONICET, in Grupo de Estudios Ambientales, \\ Universidad Nacional de San Luis, Ejercito de los Andes 950 (5700), San Luis, Argentina.
}

\begin{abstract}
Tree establishment can have multiple effects on the production and biodiversity of rangelands. In mixed (C3-C4) grasslands, winter deciduous trees could favor cold-season species in the understory, improving forage availability in the most critical time of the year. Yet, they could also promote local extinctions and invasions, risking native biodiversity. We evaluate the effect of poplar planting on the structure, composition, and diversity of native grasslands in the Flooding Pampas of Argentina using a network of 9 pairs of adjacent nonafforested and afforested stands (age: 23-25 years, density: 625-1 111 plants ha $^{-1}$ ) located in different topographic positions. Phytosociological surveys, basal cover measurements, and tree volume were performed at all stands. Live plant cover was $42 \%$ lower under poplars $(P<0.05)$. Litter cover followed an opposite trend leaving bare soil proportions unchanged with afforestation. Afforested stands had a higher proportion of C3 species compared with nonafforested ones. Little evidence of local extinctions or invasions with afforestation was found. Poplar understories had significantly higher nonnative species cover but similar numbers and lower species diversity (Shannon-Weaver index) yet similar species richness when compared with their nonafforested counterparts. Beyond the diversification of ranch outputs, deciduous tree plantations in the Flooding Pampas can offer a good forage source in their understory that complements nonafforested natural grasslands in quality and seasonality.
\end{abstract}

\section{Resumen}

El establecimiento de árboles puede tener múltiples efectos sobre la producción y la biodiversidad de pastizales. En praderas mixtas (C3-C4), los árboles deciduos podrían favorecer a las especies invernales del estrato herbáceo, mejorando la disponibilidad de forraje en el período más crítico del año. Sin embargo, los árboles también podrían promover extinciones e invasiones locales, amenazando la biodiversidad del sistema. Evaluamos los efectos de la forestación con álamos sobre la estructura, composición y diversidad florística de pastizales naturales en la Pampa Inundable de Argentina utilizando una red de nueve sitios apareados integrados por stands adyacentes de pastizal no forestado y forestado (edad: 23-25 años, densidad: 6251111 plantas $\mathrm{ha}^{-1}$ ) ubicados en diferentes posiciones topográficas. Se llevaron a cabo censos fitosociológicos, medidas de cobertura basal, y del volumen de árboles en todos los sitios. La cobertura de plantas vivas fue $42 \%$ menor bajo los álamos $(P<0.05)$. La cobertura de broza mostró una tendencia opuesta, manteniendo la proporción de suelo desnudo sin cambios tras la forestación. Los stands forestados tuvieron una mayor proporción de especies C3 comparados con los no forestados. Se encontraron pocos indicios de extinciones o invasiones locales asociados a la forestación. Las comunidades herbáceas bajo álamos tuvieron significativamente mayor cobertura de especies no nativas pero igual riqueza de las mismas comparadas con las situaciones no forestadas. La diversidad total de especies vegetales fue menor (índice de Shannon-Weaver) en los stands forestados pero la riqueza fue similar en ambas situaciones. Más allá de la diversificación de la producción, las plantaciones de especies forestales deciduas en la Pampa Inundable pueden albergar una buena fuente de forraje en su sotobosque, capaz de complementar a la de los pastizales naturales no forestados en calidad y estacionalidad.

Key Words: Argentina, C3/C4 species, cottonwood, Populus deltoides, silvopastoral systems, temperate grassland

\section{INTRODUCTION}

In silvopastoral systems, pastures, domestic herbivores, and tree crops are combined to enhance production per unit of area and promote the diversification of ranch outputs and risks (Von Maydell 1985; Pearson and Ison 1997). The complementary use

This research was funded by the Inter-American Institute for Global Change (IAI-SGP 004) and Fundación Antorchas (career start-up grant).

Correspondence: Esteban G. Jobbágy, CONICET, in Grupo de Estudios Ambientales, Universidad Nacional de San Luis, Ejercito de los Andes 950 (5700), San Luis, Argentina. Email: jobbagy@unsl.edu.ar

Manuscript received 28 September 2004; manuscript accepted 25 April 2005. of resources between herbaceous and woody plant components in these systems is a key aspect of their success and can be favored through the selection of trees and grasses with decoupled phenologies (Ong and Leakey 1999; Roupsard et al. 1999). We suggest that this temporal decoupling may develop spontaneously when mixed temperate grasslands are afforested with winter-deciduous trees. A higher temporal overlap and competition between trees and warm season grasses could indirectly favor the cold season components of the grasslands, leading to their dominance in the herbaceous canopy. To evaluate this hypothesis we characterize the structural and floristic changes taking place in native grasslands of the Flooding Pampa that have been afforested with poplars. 
Table 1. Study sites grouped according to their topographic position and property. Location, size, age, and initial planting density of afforested stands are indicated. Depths to the upper limit of the Bt horizon were used to select stands with similar soils within sites, and the range of values found in each case is shown. Grazing management at each site (same for afforested and nonafforested stands) is indicated. Site $\mathrm{J}$ did not include a grassland pair.

\begin{tabular}{|c|c|c|c|c|c|c|c|c|}
\hline Position & Ranch & Site & $\begin{array}{l}\text { Location } \\
\text { (lat/long) }\end{array}$ & $\begin{array}{c}\text { Plantation } \\
\text { size } \\
\text { (ha) }\end{array}$ & $\begin{array}{l}\text { Age } \\
\text { (yrs) }\end{array}$ & $\begin{array}{l}\text { Planting } \\
\text { density } \\
(\text { trees } \\
\text { ha }^{-1} \text { ) }\end{array}$ & $\begin{array}{c}\text { Bt } \\
\text { horizon } \\
\text { depth } \\
(\mathrm{cm})\end{array}$ & Grazing $^{1}$ \\
\hline \multirow[t]{5}{*}{ Upland } & Los Ombúes & $A$ & $-36.04 /-57.83$ & 0.7 & 25 & 1111 & $>100$ & C \\
\hline & & $B$ & $-36.04 /-57.83$ & 5.2 & 25 & 1111 & $>100$ & C \\
\hline & San Narciso & C & $-36.10 /-57.89$ & 3.5 & 23 & 625 & 45 & 1 \\
\hline & & $\mathrm{D}$ & $-36.12 /-57.87$ & 4.5 & 22 & 1111 & $40-75$ & I \\
\hline & & (J) & $-36.08 /-57.83$ & 2.9 & 23 & 1111 & $45-50$ & $N G$ \\
\hline \multirow[t]{5}{*}{ Lowland } & Los Ombúes & $E$ & $-36.05 /-57.84$ & 0.6 & 25 & 1111 & 41 & $\mathrm{C}$ \\
\hline & & $\mathrm{F}$ & $-36.04 /-57.84$ & 0.2 & 25 & 1111 & $40-47$ & C \\
\hline & San Narciso & G & $-36.12 /-57.87$ & 0.5 & 23 & 1111 & 44 & I \\
\hline & & $\mathrm{H}$ & $-36.12 /-57.87$ & 2.1 & 23 & 625 & 44 & 1 \\
\hline & & 1 & $-36.12 /-57.89$ & 7.4 & 23 & 1111 & 40 & I \\
\hline
\end{tabular}

${ }^{1}$ Grazing management: C (continuous), I (intermittent), and NG (no grazing).

A temperate climate with mild winters and uniform precipitation inputs throughout the year warrants the coexistence of C3 and C4 species across the Flooding Pampa (Paruelo et al. 1999; Perelman et al. 2001). These 2 groups have balanced cover proportions in uplands, whereas C4 species tend to dominate in lowlands (Perelman et al. 2001) and in areas subject to excessive or poorly managed grazing (Jacobo et al. 2000). The native grasslands of the Flooding Pampas have their minimum primary production in winter (Sala et al. 1981; Paruelo et al. 2001), and forage availability during this season often dictates livestock carrying capacity throughout the whole year (Jacobo et al. 2000). Strategies to increase winter forage availability, such as annual C3 grasses sowing and facilitation with grazing and/or herbicide pulses, have a high impact on the secondary production and overall success of local ranches (Jacobo et al. 2000). Afforestation with winter-deciduous trees in these grasslands may offer an alternative way to promote winter forage production and enhance the overall quality of herbaceous biomass by favoring the dominance of $\mathrm{C} 3$ grasses. At the same time, timber production could diversify ranch outputs in a region in which agriculture is severely limited by periodic flooding and soil salinity and sodicity. Surprisingly, the variations that afforestation induces on grassland structure and composition have been poorly described.

We evaluated the effects of eastern cottonwood poplar (Populus deltoides Bartr. ex Marsh. ssp. deltoides) on grassland communities of the Flooding Pampa focusing on the following questions: Is the abundance of herbaceous plants and bare soil proportion affected by tree establishment? Are there changes in the functional composition of herbaceous canopies (grass/ sedge/dicot, C3/C4, annual/perennial proportions)? Is biodiversity, measured in terms of the ratio of native to nonnative species or plant species richness and diversity, influenced? How do timber production rates change across the main environmental gradient? We used a network of 9 sites with adjacent afforested and nonafforested stands distributed along a topo- graphic gradient that represented the most typical environments of the region to address these questions.

\section{MATERIALS AND METHODS}

\section{Study Sites}

Sites were located in the vicinity of Castelli (lat $-36^{\circ} 06^{\prime}$, long $-57^{\circ} 48^{\prime}$; Buenos Aires Province, Argentina), where mean annual temperature and precipitation are $15.3^{\circ} \mathrm{C}$ and 980 $\mathrm{mm}$, respectively (Jobbágy and Jackson 2004). The area represents the extremely flat and poorly drained landscape of the Flooding Pampa and was originally occupied by native grasslands in which woody species were completely absent (Soriano et al. 1992). Gentle topographic gradients dictate environmental heterogeneity and soils, generally of silty-loam texture in the surface and clay-loam texture in the B horizon, graded from fertile Mollisols in uplands to sodic and hydromorphic Mollisols and Alfisols in lower positions. Flooding in lowland areas is frequent during fall, winter, and spring. Summer droughts are common and more pronounced in the uplands (Taboada and Lavado 1988). Grassland heterogeneity is explained by this topographic gradient and its interaction with grazing (Perelman et al. 2001). In this work, we included communities from uplands and midslope lowlands (communities "A" and "B" according to Burkart et al. 1990), discarding the lowest positions in the landscape, typically occupied by strongly alkaline soils and permanently flooded areas, because of their poor suitability for tree planting.

Sites were located in upland (A to D) and lowland (E to I) positions. Each site included 2 physiognomies, characterized by pairs of adjacent afforested (A to I) and nonafforested stands $\left(\mathrm{A}^{\prime}\right.$ to $\left.\mathrm{I}^{\prime}\right)$. Sites were located within 2 calving ranches, "Los Ombúes" (sites: A, B, E, and F) and "San Narciso" (sites: C, D, G, H, I, and J). Both stands in each pair were located on the same topographic position and shared the same soil type, as confirmed by direct observation in the field and similar depth to the $\mathrm{B}$ horizon $( \pm 10 \mathrm{~cm})$. An additional upland poplar stand $(\mathrm{J})$ was sampled, although no suitable grassland stands were found for comparison. Data from this site was used to evaluate the performance of trees and to speculate about grazing effects on the understory composition because it represented the only stand in which cattle were excluded. All the afforested stands were planted with eastern cottonwood poplar (I63, I64, I74, and 176 clones). Tree stands had $0.5-5$ ha and were planted between 1979 and 1981 (22 to 24 years of age at the time of our measurements) with densities of either 625 or 1111 plants $\mathrm{ha}^{-1}$ (Table 1). Hole-digging for individual plants was the only disturbance associated with tree establishment. No plowing, fertilization, or irrigation were ever applied, and plantations were never thinned or pruned. Sites C, D, G, and H were sowed 4 years before tree planting with tall fescue (Festuca arundinacea Schreb.), whereas the rest of the sites were occupied by native communities at the time of planting.

\section{Data Collection and Analysis}

To characterize herbaceous floristic composition, we recorded all species present in an area of $\sim 0.5$ ha and measured the basal cover of live herbaceous plants (discriminated by species), 
herbaceous litter, poplar litter, and bare soil along 2 randomly located, 4-m-long transects that were always $>20 \mathrm{~m}$ away from the plantation-grassland edge. Basal cover measurements considered the linear segments of the transect that were occupied by live plant tissues, litter, and bare soil at the ground surface. Resolution in these measurements was $1 \mathrm{~cm}$, and where pieces of plants or litter $<1 \mathrm{~cm}$ thick appeared intermingled with bare soil, we visually estimated the proportion of the area occupied by each phase adjusting the interception values. All measurements were performed between August of 2002 and March of 2003. Tree density was measured by counting live, dead, and missing trees in the initial planting positions along 2100 -m-long transects. Based on herbaceous cover measurements, we calculated the relative contribution of different groups according to the following classifications: a) growth form: grass, sedge, or dicot; b) photosynthetic syndrome $\mathrm{C} 3$ or $\mathrm{C} 4$; and c) life cycle: annual or perennial. Proportional values from the 2 transects of each stand were averaged and arcsine-transformed to normalize distributions and homogenize variances.

To characterize biodiversity changes with afforestation, we computed the relative contribution of nonnative species in each stand both in terms of cover proportion and species number. In addition, we considered species richness (total species count in $0.5 \mathrm{ha}$ ) and species diversity (Shannon-Weaver index for the pool of 2 transects) in each stand. Pastoral quality was assessed with the following index (Daget and Poissonet 1971; Cauhépé et al. 1985):

$$
F Q=\sum C s i \times I s i / \sum C s i
$$

in which Csi represents the proportion of the ground covered by species $i$, and $I s i$ characterizes the species quality from 0 to 1. based on data from Cauhépé et al. (1985) and expert opinion (V.A. Deregibus personal communication, April 2003). The index eliminates differences that result from total plant cover and represents the mean quality of the community. To assess timber production rates, we measured tree diameter (breast height $=1.3 \mathrm{~m}$ ) and height and calculated the volume of the main stem using shape coefficient of $0.5 \mathrm{~m}^{3} / \mathrm{m}^{3}$, typical for cottonwood poplars in the Pampas (E. Borodowsky, personal communication, February 2003).

Differences between afforested and nonafforested stands and their interaction with topographic position were assessed using a 2-way analysis of variance (ANOVA) in which afforestation effects across stands were fixed within sites to represent the paired structure of the observations. This approach, typically used to explore changes through time after treatment application, was used in a spatial context under the assumption that in our paired design, grassland stands represented the vegetation that afforested stands had before tree establishment. This analysis was applied to all the variables that could be normalized, exceptions being species diversity and richness. In these cases we used the Kruskal-Wallis test.

To identify possible extinctions, we looked for species that had $>50 \%$ frequency in grassland stands but which were totally absent under tree plantations. We explored potential invasions by looking for species that, being absent in the Flooding Pampas flora (León et al. 1979), were present in at least 1 of our afforested stands. We also identified species that displayed significant abundance shifts between nonafforested and afforested pairs using paired $t$-test, considering only species with $>50 \%$ frequency in grassland stands.

\section{RESULTS}

Afforested stands had lower live herbaceous plant cover than their adjacent nonafforested ones. This, however, did not translate into higher proportions of bare soil because of poplar litter contributions. Live plant cover was $42 \%$ lower under poplars, in comparison with nonafforested stands, whereas litter cover was twice as large, and bare soil was not significantly affected (Table 2). Topography had no significant influence on these variables and showed no interaction with afforestation (Table 2).

The effects of afforestation on growth form composition were on average nonsignificant (Table 2). There was, however, an interaction with topography in the case of grass cover. What was only a nonsignificant trend of grass cover increase with afforestation in uplands $(57 \pm 11 \% \quad[$ mean \pm SD] vs. $40 \pm 18 \% \mathrm{SD}$, in afforested and nonafforested stands, respectively) became a significant effect in lowlands, where the dominant growth form switched from dicots in nonafforested stands to grasses in tree plantations $(24 \pm 7 \%$ SD vs. $8 \pm 3 \%$ $\mathrm{SD}$, in afforested and nonafforested stands, respectively). Besides afforestation effects, sedges and dicots were more abundant toward lowland positions (Table 2). Compared with nonafforested stands, tree plantations had a higher proportion of C3 species (Fig. 1, Table 2) but a lower absolute ground cover for the group $(32 \%$ vs. $39 \%, P=0.03)$. The proportion of annual species did not differ significantly with tree planting or topographic position (Table 2).

Biodiversity changes in relation to afforestation were manifested as an increase of nonnative species cover (but not number) and a decline of species diversity (Fig. 1, Table 2). Species richness was strongly affected by topography but not afforestation, with afforested stands having on average $\sim 3$ species less than nonafforested ones (Table 2). Topography had an overwhelming effect on biodiversity, with significant declines in species richness and nonnative species cover and number occurring towards lowlands (Table 2). Although there was an overall positive effect of tree plantations on pastoral quality (Table 2), these effects interacted with topography, being significant in uplands $(P<0.05)$, where pastoral quality was higher in general, but not in lowlands $(P=0.23)$, where the lowest pastoral quality was recorded (Table 2 ).

Only 1 local extinction was detected (Table 3), corresponding to the forb Phyla canescens (Kunth) Greene, present in all nonafforested lowland stands was totally absent under poplars. Although no specific invasions were identified, saplings of Laurus nobilis L. and Morus alba L. were found in the only afforested stand that was excluded from domestic grazers (upland stand J). Compared with adjacent nonafforested stands, tree plantations showed a significantly lower absolute abundance for 3 typically dominant C4 grasses of the Paspalum and Paspalidium genera, whereas the nonnative C3 grass Festuca arundinacea Schreb. showed the opposite trend (Table 3).

The mean annual volumetric increment of poplar stems was higher in upland than in lowland sites $\left(13.6 \pm 5.2 \mathrm{~m}^{3} \mathrm{ha}^{-1}\right.$ year ${ }^{-1} \mathrm{SD}$ vs. $7.4 \pm 4.6 \mathrm{~m}^{3} \mathrm{ha}^{-1}$ year $\left.^{-1} \mathrm{SD}, P<0.05\right)$. Tree 
Table 2. Vegetation structure according to topographic position (upland vs. lowland) and afforestation situation (afforested vs. nonafforested). Ground cover partition among plants, litter, and bare soil is indicated. The functional composition of stands is characterized according to the relative contribution of species with different photosynthetic syndromes (C3 vs. C4), life cycles (annual vs. perennial), and growth forms (grass, sedge, and dicot). Biodiversity is characterized by the relative abundance of nonnative species (cover and species number), species richness and diversity (Shannon-Weaver index), and pastoral quality (index that increases from 0 to 1 with species value). All values in the first 4 columns correspond to mean and standard deviation. The $P$-values for topography (top) and afforestation (aff) effects and their interaction are indicated. They were derived from a 2-way ANOVA with fixed effects for afforestation, except for species richness and diversity, which were analyzed with Kruskall-Wallis ANOVA. $P$-valves lower than 0.05 in bold.

\begin{tabular}{|c|c|c|c|c|c|c|c|}
\hline & \multicolumn{2}{|c|}{ Upland } & \multicolumn{2}{|c|}{ Lowland } & \multicolumn{3}{|c|}{ ANOVA } \\
\hline & nonafforested & afforested & nonafforested & afforested & top & aff & top $\times$ aff \\
\hline \multicolumn{8}{|l|}{ Ground cover } \\
\hline Plant (\%) & $76.4(10.4)$ & $46.4(24.5)$ & $54.8(8.2)$ & $30.7(14.7)$ & 0.087 & 0.0003 & 0.500 \\
\hline Litter (\%) & $17.3(6.8)$ & $43.5(20.0)$ & $29.9(17.2)$ & $49.1(13.0)$ & 0.327 & 0.003 & 0.525 \\
\hline Bare soil (\%) & $5.5(9.9)$ & $9.6(6.6)$ & $15.4(11.4)$ & $21.1(9.0)$ & 0.065 & 0.269 & 0.848 \\
\hline \multicolumn{8}{|l|}{ Functional composition } \\
\hline \multicolumn{8}{|l|}{ Growth form (\% cover) } \\
\hline grasses & $74.5(10.6)$ & $89.1(12.7)$ & $29.5(11.5)$ & $45.0(14.1)$ & 0.0003 & 0.934 & 0.020 \\
\hline sedges & $5.6(4.9)$ & $2.8(3.1)$ & $26.5(20.4)$ & $26.0(8.8)$ & 0.002 & 0.868 & 0.818 \\
\hline dicots & $19.8(11.5)$ & $8.0(9.7)$ & $44.0(21.0)$ & $29.0(14.2)$ & 0.029 & 0.800 & 0.062 \\
\hline Phot. syndrome (\% C3 cover) & $57.3(9.8)$ & $84.6(12.8)$ & $65.7(10.2)$ & $92.2(5.0)$ & 0.121 & 0.001 & 0.939 \\
\hline Life cycle (\% annual cover) & $12.2(6.5)$ & $13.8(8.6)$ & $0.4(0.9)$ & $21.4(44.0)$ & 0.859 & 0.363 & 0.434 \\
\hline \multicolumn{8}{|l|}{ Biodiversity } \\
\hline Nonnatives (\% cover) & $37.6(11.8)$ & $75.1(21.7)$ & $1.4(1.7)$ & $11.4(14.4)$ & 0.0001 & 0.013 & 0.096 \\
\hline Nonnatives (\% species) & $29.1(2.1)$ & $33.6(3.8)$ & $25.3(5.8)$ & $26.3(9.9)$ & 0.009 & 0.919 & 0.479 \\
\hline Richness (species number) & $31.0(4.4)$ & $27.5(9.7)$ & $20.8(5.4)$ & $17.6(4.8)$ & 0.022 & 0.204 & 0.952 \\
\hline Diversity (S \& W index) & $0.89(0.17)$ & $0.50(0.33)$ & $0.56(0.05)$ & $0.35(0.15)$ & 0.073 & 0.001 & 0.153 \\
\hline Pastoral quality ( 0 to 1 index) & $0.56(0.04)$ & $0.72(0.07)$ & $0.30(0.08)$ & $0.27(0.08)$ & 0.0001 & 0.044 & 0.010 \\
\hline
\end{tabular}

height averaged $19 \pm 4 \mathrm{~m} \mathrm{SD}$ and had no significant trends across topographic positions $(P=0.72$, Table 4$)$.

\section{DISCUSSION}

After more than 2 decades of their establishment, high-density poplar plantations in the Flooding Pampas maintained understory communities with more than half of the herbaceous cover

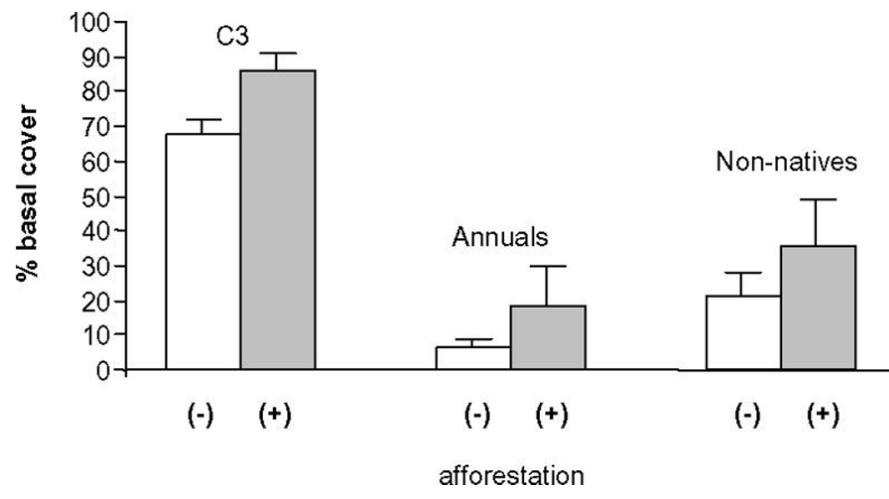

Figure 1. Relative abundance of herbaceous species according to photosynthetic syndrome, life cycle, and biogeographical origin. All classifications are dichotomous and the values of 1 of the 2 possible classes are shown as percentages. Mean and standard deviation values across all study sites are shown. found in nonafforested grasslands, suggesting, in principle, the ecological feasibility of silvopastoral systems in these grasslands.

The most important change in the functional composition of understory communities was the widespread increase of C3 species cover, followed by the increase of grasses at the expense of dicot species observed in low topographic positions. Trees shifted the relative abundance of C3 grasses to levels that are rarely seen in the native vegetation of the Pampas (usually $<65 \%$, León and Burkart 1998). Without trees, these levels of C3 grass dominance are only achieved in artificial pastures and usually lost within 5 years of successional changes (León and Oesterheld 1982). Trees were likely to compete with all grassland components for light, water, and nutrients; however, the relative intensity of these competitive effects was probably stronger over warm-season species. In the Flooding Pampas, C4 grasses display a spring-summer-fall cycle that is completely synchronous with the active period of poplars (approximately mid-October to mid-May), whereas C3 grasses grow actively from fall to late spring (Sala et al. 1981), taking advantage of the 5-month period in which poplars are leafless. Even when trees are active, C3 species may experience relatively less negative effects than $\mathrm{C} 4$ species because of their ability to sustain positive carbon gains at lower light intensities and because of the beneficial effect of decreased summer temperatures under tree canopies (Brown and Radcliffe 1986; Lin et al. 1999). These results suggest that the understory communities had species of more desirable quality and seasonality than their nonafforested counterparts. 
Table 3. Main specific differences associated with poplar afforestation. Extinctions involve species that, having $>50 \%$ frequency in nonafforested stands, were absent in afforested ones. Invasions correspond to species that, being absent in the regional flora, occurred in $\geq 1$ afforested stand. Abundance shifts were explored for species with $>50 \%$ frequency in grassland stands and represent cases in which significant $(P<0.05)$ cover changes were detected using a paired $t$-test. Absolute cover shifts, calculated as the percentage change in afforested stands with respect to nonafforested ones, are indicated for these species.

\begin{tabular}{llll}
\hline & \multicolumn{1}{c}{ Species } & \multicolumn{1}{c}{ Functional description } & Observations \\
\hline Extinctions & Phyla canescens & perennial forb, native & Very frequent in grassland stands \\
Invasions & Laurus nobilis & evergreen tree, nonnative & Absent in the region, bird dispersed \\
& Morus alba & deciduous tree, nonnative & Absent in the region, bird dispersed \\
Abundance shifts & Paspalidium paludivagum & C4 perennial grass, native & $95 \%$ decline \\
& Paspalum dilatatum & C4 perennial grass, native & $74 \%$ decline \\
& Paspalum vaginatum & C4 perennial grass, native & $85 \%$ decline \\
& Festuca arundinacea & C3 perennial grass, nonnative & $67 \%$ increase \\
\hline
\end{tabular}

In terms of grassland biodiversity, the most important changes associated with poplar establishment were the overall increase in nonnative species cover and the decline on the diversity indexes, associated to the increased dominance of a few C3 grasses. Strong structural and functional changes in afforested grasslands were not accompanied by significant local extinctions, with the exception of a frequent, yet small, forb species (Table 3). C4 grasses experienced sharp cover declines but did not disappear completely underneath poplars. The presence of many shade-intolerant species in small tree plantations, like the ones we studied $(<5$ ha $)$, may have been warranted by continuous arrival of seeds from adjacent grassland (mass effect, Shmida and Wilson 1985). This effect may become less important and extinctions more likely in larger plantations.

Invasive woody species together with self-regenerating plantation species represent a potential risk in silvopastoral systems, where they can encroach and dominate the understory, limiting its grazing use (Kidd and Pimentel 1992). Tree plantations in the Pampas have been shown to host myriads of spontaneous nonnative trees and shrubs that are completely absent in the grasslands, pastures, and croplands of the region (Ghersa and León 2001; Jobbágy and Jackson 2003). In spite of this earlier information, no significant invasions were recorded at our sites, with one important exception, the presence of nonnative tree saplings in the only nongrazed plantation that we sampled. This exceptional case suggests that grazing may have prevented woody species occurrence in the rest of the stands, something that will require additional observation and exclosure experiments for clarification. In our sites, the use of clonal poplars that do not reproduce sexually or vegetatively warranted the lack of regeneration. This is an aspect that should be considered in future silvopastoral designs.

Tree plantation achieved reasonable timber production rates in most of our study sites. It is important to highlight that lowland plantations, in spite of having similar mean production rates as those in the uplands, were more variable, suggesting a more uncertain success in these environments. The timber production rates presented here may underestimate the potential performance of cottonwood poplars in the region because of the lack of management and the saturation of growth with age in many of the studied stands, where a large density of standing dead trees of small size suggested self-thinning in some tree stands.

\section{MANAGEMENT IMPLICATIONS}

Beyond the diversification of ranch outputs, silvopastoral systems in the Flooding Pampas, as well as in other temperate grasslands of the world devoted to animal production, can offer a good forage source that complements natural grasslands in quality and seasonality. We have shown how a deciduous tree species reversed the natural trend of $\mathrm{C} 4$ dominance in these grasslands, highlighting the value of tree canopies as a grassland improvement tool. Besides their productive benefits, the tree plantations that we studied had a relatively small impact on grassland biodiversity, particularly if they are compared with the typical commercial plantations of evergreen species (Pinus and Eucalyptus spp.) that usually host no understory (Jobbágy and Jackson 2003). In the context of a fast expansion of forestry over native grasslands of Argentina and Uruguay (Wright et al. 2002), deciduous silvopastoral systems may represent a more ecologically sound alternative to traditional pine and eucalyptus afforestation, one that may be capable of generating forest products and preserving grassland biodiversity and ranching activities at the same time.

Table 4. Structural characteristics of poplar plantations. All values indicate the mean for each stand and correspond to current density, height $(\mathrm{H})$, diameter at breast height $(\mathrm{DBH})$, basal area $(\mathrm{BA})$, main-stem volume (VOL), and mean annual volumetric increment (MAVI).

\begin{tabular}{|c|c|c|c|c|c|c|}
\hline Site & $\begin{array}{c}\text { Density } \\
\left(\text { trees } \cdot \text { ha }^{-1}\right)\end{array}$ & $\mathrm{H}(\mathrm{m})$ & $\mathrm{DBH}(\mathrm{m})$ & $\mathrm{BA}\left(\mathrm{m}^{2}\right)$ & $\begin{array}{c}\text { Vol } \\
\left(\mathrm{m}^{3} \cdot \mathrm{ha}^{-1}\right)\end{array}$ & $\begin{array}{c}\text { MAVI } \\
\left(\mathrm{m}^{3} \cdot \mathrm{ha}^{-1} \cdot \mathrm{y}^{-1}\right)\end{array}$ \\
\hline A & 805 & 15.6 & 0.20 & 25.3 & 197 & 7.9 \\
\hline B & 622 & 19.0 & 0.21 & 21.5 & 205 & 8.2 \\
\hline C & 453 & 20.0 & 0.32 & 36.4 & 364 & 15.8 \\
\hline D & 797 & 22.4 & 0.25 & 39.1 & 438 & 19.9 \\
\hline E & 722 & 17.8 & 0.23 & 30.0 & 267 & 10.7 \\
\hline $\mathrm{F}$ & 722 & 15.3 & 0.20 & 22.7 & 173 & 6.9 \\
\hline G & 444 & 15.5 & 0.21 & 15.4 & 119 & 5.2 \\
\hline $\mathrm{H}$ & 254 & 14.4 & 0.14 & 3.9 & 28 & 1.2 \\
\hline I & 711 & 22.1 & 0.22 & 27.0 & 299 & 13.0 \\
\hline J & 469 & 25.7 & 0.27 & 26.8 & 345 & 15.0 \\
\hline
\end{tabular}




\section{ACKNOWLEDGMENTS}

The Castrillón, Mazzini, and Ochoa families and Mrs Viscomi and Guerrero provided support in the field. Juan Carlos Villardi supplied technical assistance. Martín Oesterheld, Marcelo Nosetto, Esteban Borodowsky, Patricia Cornaglia, and Gustavo Schrauf provided useful comments at various stages of our study. The associate editor and an anonymous reviewer supplied valuable guidelines to improve the manuscript.

\section{LITERATURE CITED}

Brown, R. H., And E. B. Radcliffe. 1986. Comparison of apparent photosynthesis in sericea lespedeza and alfalfa. Crop Science 26:1208-1211.

Burkart, S. E., R. J. C. León, And C. P. Movia. 1990. Inventario Fitosociológico del Pastizal de la Depresión del Salado (Prov. Bs. As.) en un área representativa de sus principales ambientes (in spanish). Darviniana. 30:27-69.

Caumépé, M. A., L. G. Hidalgo, and A. Galatoire. 1985. Aplicación de un índice de valoración zootécnica en pastizales de la Depresión del Salado (in spanish). Revista Argentina de Producción Animal 5:680-690.

Daget, P., AND J. Poissonet. 1971. Une mèthode danalyse phytologique des prairies: critères d́application (in French). Annales de Agronomie 22:4-41.

Ghersa, C. M., And R. J. C. León. 2001. Ecología del paisaje pampeano: consideraciones para su manejo y conservación (in spanish). In: Z. Naveh, A. S. Lieberman, F. 0. Sarmiento, C. M. Ghersa, and R. J. C. León [EDS.], Ecología de paisaje, teoría y aplicación. Buenos Aires, Argentina: Editorial Facultad de Agronomía. p 471-512.

Jacobo, E. J., A. M. Rodriguez, J. L. Rossi, L. P. Salgado, and V. A. Deregibus. 2000. Rotational stocking and production of Italian ryegrass on Argentinean rangelands. Journal of Range Management 53:483-488.

Jobbágy, E. G., and R. B. Jackson. 2003. Patterns and mechanisms of soil acidification in the conversion of grasslands to forests. Biogeochemistry 64:205-229.

KIDD, C. V., AND D. PImentel. 1992. Integrated resource management: Agroforestry for development. Orlando, FL: Academic Press, Harcourt Brace Jovanovich, Publishers. $223 \mathrm{p}$.

León, J. R. C., And M. Oesterheld. 1982. Envejecimiento de pasturas implantadas en el norte de la Depresión del Salado: un enfoque sucesional (in spanish). Revista Facultad de Agronomía 3:41-49.

León, R. J. C., and S. E. BuRKart. 1998. El pastizal de la Pampa Deprimida: estados alternativos (in spanish). Ecotrópicos 11:121-130.

León, R. J. C., S. E. Burkart, And C. P. Movia. 1979. La vegetación de la República Argentina. Relevamiento fitosociológico del pastizal del norte de la Depresión del Salado (Partido de Magdalena y Brandsen, prov. de Bs. As.) (in spanish). Buenos Aires, Argentina: Instituto Nacional de Tecnología Agropecuaria. Serie Fotogeográfica 17:11-93.
Lin, C. H., R. L. McGraw, M. F. George, and H. E. Garrett. 1999. Shade effects on forage crops with potential temperate agroforestry practices. Agroforestry Systems 44:109-119.

Mazia, C. N., E. J. Chaneton, C. M. Ghersa, and J. R. C. León. 2001. Limits to tree species invasion in pampean grassland and forest plant communities. Oecología 128:594-602.

ONG, C. K., AND R. R. B. LEAKEY. 1999. Why tree-crop interactions in agroforestry appear at odds with tree-grass interactions in tropical savannahs. Agroforestry Systems 45:109-129.

Paruelo, J. M., J. P. Guerschman, and M. Oesterheld. 1999. Caracterización regional de los recursos forrajeros de las zonas templadas de la Argentina mediante imágenes satelitarias (in spanish). Revista Argentina de Producción Animal 19:121-125.

Paruelo, J. M., E. G. Jobbágy, and O. E. Sala. 2001. Current distribution of ecosystem functional types in temperate South America. Ecosystems 4:683-698.

Pearson, C. J., and R. L. Ison. 1997. Agronomy of grassland systems. 2nd ed. Cambridge, UK: Cambridge University Edition. 234 p.

Perelman, S. B., R. J. C. León, and M. Oesterheld. 2001. Cross-scale vegetation patterns of Flooding Pampa grasslands. Journal of Ecology 89:562-577.

Rodriguez, A. M., E. J. Jacobo, and V. A. Deregibus. 1998. Germination behaviour of Italian ryegrass in flooding pampa rangelands. Seed Science Research 8: 521-528.

Roupsard, 0., A. Ferhi, A. Granier, F. Pallo, D. Depommier, B. Mallet, H. I. Joly, and E. DREYER. 1999. Reverse phenology and dry-season water uptake by Faidherbia albida (Del.) A. Chev. in an agroforestry parkland of Sudanese West Africa. Functional Ecology 13:460-472.

Sala, O. E., V. A Deregibus., T. Schlichter, and H. Alippe. 1981. Productivity dynamics of a native temperate grassland in Argentina. Journal of Range Management 34:48-51.

Shannon, C. E., And W. Weaver. 1949. The mathematical theory of communication. Urbana, IL: University Illinois Press. $144 \mathrm{p}$.

ShmidA, A., AND M. W. Wilson. 1985. Biological determinants of species diversity. Journal of Biogeography 12:1-20.

Soriano, A., R. J. C. León, O. E. Sala, R. S. Lavado, V. A Deregibus, M. A. Caumepé, O. A. Scaglia, C. A. Velázquez, and J. H. Lemcoff. 1992. Río de la Plata grasslands. In: R. T. Coupland [ed.]. Ecosystems of the world, 8A-Natural grasslands: Introduction and western hemisphere. New York, NY: Elsevier. p 367-407.

TaboadA, M. A., And R. S. Lavado. 1988. Grazing effects of the soil bulk density in a Natraquoll of the Flooding Pampa of Argentina. Journal of Range Management 41:502-505.

Von MaydelL, H. J. 1985. The contribution of agroforestry to world forestry development. Agroforestry Systems 3:83-90.

Wright, J. A., A. DI Nicola, And E. Gaitan. 2000. Latin American forest plantationsopportunities for carbon sequestration, economic development and financial returns. Journal of Forestry 98:20-23. 